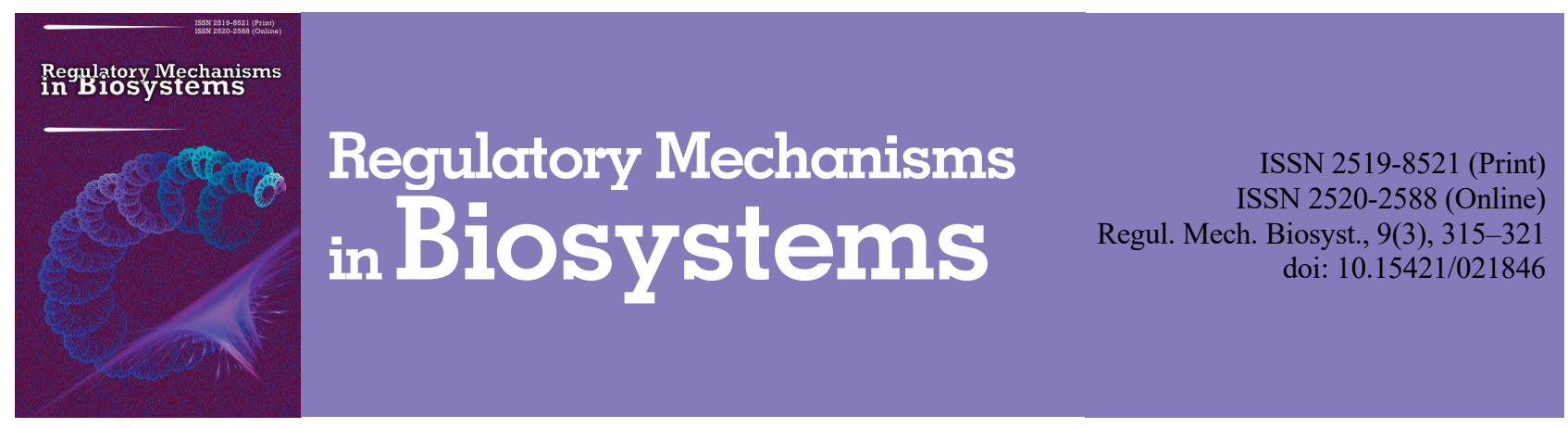

\title{
Diagnostic value of biochemical markers of bone metabolism in treatment of generalized periodontitis in patients with age-related osteoporosis
}

\author{
O. O. Fastovets, I. V. Masheiko, H. B. Peleshenko \\ Dnipro Medical Academy of the Ministry of Health of Ukraine, Dnipro, Ukraine
}

Article info

Received 24.05.2018

Received in revised form 20.06.2018

Accepted 23.06.2018

Dnipro Medical Academy of the Ministry of Health of Ukraine, Vernadsky st., 9 , Dnipro, 49027, Ukraine. Tel.: +38-097-992-11-24 E-mail:fastovets.e@ex.ua

\begin{abstract}
Fastovets, O. O., Masheiko, I. V., \& Peleshenko, H. B. (2018). Diagnostic value of biochemical markers of bone metabolism in treatment of generalized periodontitis in patients with age-related osteoporosis. Regulatory Mechanisms in Biosystems, 9(3), 315-321. doi:10.15421/021846
\end{abstract}

The topicality of the problem of periodontal diseases is due to their significant prevalence. The purpose of this work is to study the dynamics of markers of bone metabolism in the process of treatment of generalized periodontitis of the II-III levels of severity in patients with age-related osteoporosis and without osteoporotic changes in the skeleton. The examination and treatment of 104 patients, aged 63-78, equal ratio of men and women, was conducted. Among the selected patients, 49 persons had normal bone mineral density, while the remaining 55 had osteoporotic changes in the bone tissue of involutory genesis. All subjects were assessed for the following indicators ; mineral density of jaw bone tissue (BMD) according to the results of the computer tomography, the concentration of C-Propeptide of Type I Procollagen (CICP) in blood plasma, the activity of tartrate-resistant acid phosphatase (TRAP), bone alkaline phosphatase (BAP), osteocalcin, parathyroid hormone in blood serum, concentration of $\beta$-CrossLaps in urine, total calcium and inorganic phosphorus content in blood with calculation of the $\mathrm{Ca} / \mathrm{P}$ index. It was established that in patients with periodontitis of the II-III degree there was a decrease in the BMD of the alveolar bone in comparison with the control values $(\mathrm{P}<0.05)$, whereas the presence of systemic osteopenia worsened the indices $(\mathrm{P}<0.001)$. The least osteoregenerative activity, which was characterized by the decrease in BAP, TRAP and CICP levels, was registered in patients with generalized periodontitis of the III degree on the background of age-related osteoporosis $(\mathrm{P}<0.05)$. In the patients with generalized periodontitis of the III degree of severity, at the beginning of treatment, a weak negative correlation was found between BMD and TRAP activity $(\mathrm{r}=-0.292, \mathrm{P}<0.05)$ and mean strength correlation - with $\beta$-CrossLaps in urine $(\mathrm{r}=-0.348, \mathrm{P}<0.01)$. The concentration of CICP positively correlated with the mineral density of bone tissue from the third month after the start of treatment $(\mathrm{r}=0.312, \mathrm{P}<0.05)$. As a conclusion, the mineral density of alveolar bone in the process of treatment varies unevenly depending on the severity of generalized periodontitis and the character of osteoporotic changes in the skeleton. The biochemical markers of bone metabolism allow the balance of processes of bone resorption and formation to be determined in order to correct treatment of generalized periodontitis.

Keywords: periodontal diseases; osteopenia; bone mineral density; biomarkers.

\section{Introduction}

The problem of inflammatory-dystrophic diseases of periodontal tissues is highly relevant on account of the wide distribution of this disease among the population of Ukraine, complicated by delayed diagnostics; the rapidly progressing development of the pathological process; and also by the necessity of integrated and prolonged treatment. Moreover, generalized periodontal disease is a serious socio-economic problem caused by a significant loss of teeth and decrease in the quality of life (Lu et al., 2016; Frencken et al., 2017). Currently, the diseases are classified as multi-factor diseases which are the result of interaction of the organism with the environment (Tsepov et al., 2016). Milder forms of generalized periodontal disease usually are nosologies, whereas severe forms are related to different systemic diseases which are characterized by general disorders of homeostasis (Fastovets, 2000; Linden et al., 2013). Practically always, hormonal disorders such as diabetes mellitus (Wu et al., 2015; Winning \&Linden, 2017), endemic goiter (Chornij \& Shmanko, 2017), menopause (Kolte et al., 2017; Goyal et al., 2017), states of immune deficiency, especially HIV infection (Souza et al., 2017), leukemia (Rinčić et al., 2016), and disorders of the develop- ment of connective tissue, for example its dysplasia (Kirova et al., 2009, are associated with generalized periodontal disease.

Currently, the pathogenic relation between the inflammatory process in the periodontal tissues and destructive changes in the alveolar cyst is proved (Wang \& McCauley, 2016; Kinane et al., 2017). However, recent research is not unanimous regarding the peculiarities of the development of periodontal disease during osteoporotic changes in the skeleton (Darcey et al., 2013; Chambrone, 2016), and also regarding the leading mechanism of destruction of the osseous component of periodontal disease (Bernal et al., 2018). It has been mentioned that with aggressive forms of periodontal disease, the number of osseous tooth deposits is minimum, whereas the resorption of bone tissue is significant (Clark et al., 2017).

The bone tissue is a connective tissue with a high level of mineralization of organic intercellular substance which contains around $70 \%$ of non-organic compounds, mostly calcium phosphate. Despite the high level of mineralization, constant renewal of the matrix and adaptive restructuration occurs in the bone tissues depending on the conditions of their functioning (Sims \& Gooi, 2008). The bone tissue's resistance to resorption depends on the level of its mineralization, which is determined by the main factors (Penoni et al., 2016). The main factors which 
influence the metabolism of bone tissue are the levels of calcium, phosphorus and hormones, which regulate their metabolism, circulating in the extracellular fluid (Naot \& Cornish, 2008). The most informative markers of bone metabolism, often used in clinical studies, are considered to be the tartrate-resistant acid phosphatase (TRAP) of blood serum and C-terminal Telopeptide of Type-1 Collagen ( $\beta$-CrossLaps) of urine, which reflect the activity of resorptive processes. At the same time, osteocalcin $(\mathrm{OC})$, bone alkaline phosphatase (BAP), procollagen type $1 \mathrm{C}$-terminal propeptide (CICP) of blood serum are most representative of the activity of processes of bone formation ( $\mathrm{Lu}$ et al., 2016; Garnero, 2017). On the whole, the determination of the dynamics of concentration of the markers of resorption and formation of bone tissue in biological fluids is required in order to assess the success of treatment in effecting remission of the destructive processes in the bone tissue.

Apart from the abovementioned biochemical studies, numerous noninvasive apparatus methods of diagnostics have been developed and broadly introduced into clinical practice. They allow accurate determination of the mineral density of the bone tissue (Dobrovol'skaja et al., 2017). Thus, the usage of roentgenological investigation allows not only study of the structure of bone tissue of the periodontal complex, but also determination of whether the patient is in the risk group of development of periodontal disease (Gajdarova et al., 2006; Ignasiak et al., 2016), whereas the data from orthopatomography are a reason for roentgenological densitometery (Nakamoto et al., 2008).

Finally, considering that systemic osteoporosis is a significant mechanism which leads to the development and complication of generalized periodontal disease (Bodduru et al., 2016), it is necessary to prescribe specific pathogenic therapy depending on the character of the metabolic disorders in the bone tissue (Gorb-Gavril'chenko \& Strel'chenja, 2013; Aspalli et al., 2014; Mordasov \& Ivanjuta, 2016). As a result of the close relationship between the mineral metabolism and the pattern of systemic osteoporosis, many clinicians recommend combined pharmacotherapy using anti-resorptive preparations, calcium and vitamins (Karakov, 2016). Selecting the optimum medicamental protocol, monitoring of the efficiency of treatment in dynamics, which includes timely correction, is impossible without determining and monitoring the structural-functional condition of the bone tissue (Masheiko, 2017; Roschger et al. 2008).

Therefore, considering everything stated above, the objective of this study was to determine the dynamics of biochemical markers of metabolism of bone tissue in the process of treatment of generalized periodontal disease of II-III degree among patients with age-related osteoporosis and no osteoporotic changes in the skeleton.

\section{Materials and methods}

For realisation of the goal, we conducted an integrated study and treatment of 104 patients with generalized periodontal disease of IIIII degree, aged between 63-78 years, with an equal number of men and women. To diagnose periodontal disease, we used the classification of M. F. Danilevskij (Danilevskij \& Borisenko, 2000).

Among the selected patients, 49 had normal mineral density in the bone tissue, whereas 55 had osteoporotic changes in bone tissue of involute genesis. The condition of bone tissue was determined on the bases of the results of studying the mineral density of the bone tissue (BMD) using the method of dual-energy X-ray absorptiometry using the Lunar Prodigy apparatus. Measurements were made in the lumbar vertebrae (LI-LIV), in the area of femoral neck (Neck), greater trochanter (Troch), and Ward's triangle (Ward). Diagnosing osteoporotic changes in the skeleton was conducted in accordance with the recommendations of the $\mathrm{WHO}$, criteria $\mathrm{T}$, i.e. in relation to the value of standard deviation (SD) from the normal parameters of peak bone mass of healthy individuals of a corresponding age. The SD value below 1 was considered normal, between 1 and $2.5 \mathrm{SD}$ - osteopenia, below 2.5 SD - osteoporosis (Siris et al., 2014).

Criteria for excluding patients from the scope of the study were as follows: the general diseases in the anamnesis, which could influence the mineral density of bone tissue; usage of medical preparations which contain mineral components; traumas and inflammatory diseases of the bone-joint system, breach of the treatment protocol.

Prior to the study, the patients gave written approval for being involved in the study.

The patients were divided as follows: 55 patients with senile osteoporosis were included in the first main group, group I (12 men and 15 women, who had generalized periodontal disease of II degree of severity) and the second main group, group II, which included 10 men and 18 women with aggressive (III type) disease. The comparison group was formed similarly to the main group in relation to genderage and clinical criteria from people who had normal parameters of mineral bone density. Therefore, the comparison group I included 14 men and 9 women with periodontal disease of the II type; the comparison group II - 16 men and 10 women with periodontal disease of the III type. Also, as the control, we involved 20 people of the same age group with an equal number of men and women, with conditionnally healthy periodontal tissues, who had no diagnosed osteoporotic changes in the bone tissue.

All patients suffering from generalized periodontal disease received complex treatment according to the generally accepted protocol (Borysenko et al., 2005). Prior to the treatment the patients underwent a professional hygiene regime of the oral cavity, which consisted of removing the sediments above and under the gums using the "PiezonMaster" ultrasonic system and the "Vektor" system. For providing long term stabilization of the pathological process, the dental treatment included therapeutic, surgical and orthopedic methods, and also consultations and treatment recommended by an endocrinologist.

In the scope of the presented study, all the observed patients were monitored using computer tomographic scanning of the jaw bones (Morita, Japan, 2008) to determine destructive changes in the compacted and trabecular bone, and at the same time determine the parameters of BMD in the following zones: alveolar, middle and apical horizontal, septal vertical. Alveolar horizontal was considered a conventional line which lay along the crest of alveolar process; middle horizontal - line which lay across the central part of interdental septum; apical horizontal - line which connects the tops of the roots, septal vertical - line which divides the alveolar line into equal parts in lengthwise direction. The density of the bone tissue was expressed in Hounsfield numbers $(\mathrm{H})$.

The conclusions on the activity of the processes of destructive bone tissue were made according to the level of the resorption markers. In the blood serum, we determined the activity of tartrate-resistant acid phosphatase (TRAP) (u/l) using a set of Bone-TRAP (IDS). The concentration of $\beta$-CrossLaps fragments in the urine were determined using the Serum CrossLaps (Osteometer) test-system.

For standard excretion of $\beta$-CrossLaps, we used the second spontaneous morning sample of urine with following normalization of its concentration to the amount of creatinine in the analyzed sample. The results were converted into ng $\beta$-CrossLaps to $1 \mathrm{~g}$ of creatinine.

The activity of recovery of the bone tissue was determined according to the concentration of procollagen type $1 \mathrm{C}$-terminal propeptide (CICP) in the blood serum, which was determined using the method of immune-enzymic analysis with Metra CIPC EIA Kit («Quidel Corporation», USA) diagnostic set, bone alkaline phosphatase (BAP) in the blood serum using kinetic colorimetric method (U/l), osteocalcin with N-MID Osteocalcin ELISA (USA) test set.

In addition, we calculated the parameters of mineral metabolism concentration of parathyroid hormone in the blood serum using the "I-PTH ELISA" (DSL, USA) test-system; the content of total calcium in the blood by the colorimetric method with Ortho-CresolPhthalein (Kapitanenko \& Dochkin, 1988); the content of total non-organic phosphorus in the blood by the colorimetric method according to the reaction with Molybdenum-Vanadium reagent (mmol/l) (Kondrahin, 2004) with following calculation of the $\mathrm{Ca} / \mathrm{P}$ proportion.

The obtained data were statistically analyzed in Statistica 6.0 (Statsoft Inc., USA) pack using the calculation of the Student's t-criterion at normal distribution of the data and non-parametric MannWhitney test criterion at not normal distribution. The normal distribution was calculated using the Shapiro-Wilk test criterion. Differences 
at $\mathrm{P}<0.05$ were considered statistically reliable (Filimonova et al., 2004; Filimonova \& Fil', 2005).

\section{Results}

As we see from the data provided in Table 1, in each group, the most significant changes in the bone tissue density which occurred as a result of the course of treatment were observed in the septal vertical, and also in the alveolar and middle horizontals, i.e. in the areas directly involved in the pathological process of generalized periodontal disease. At the same time, in the alveolar horizontal, the BMD parameters were higher $(\mathrm{P}<0.05)$, though the dynamics of the changes in the process of treatment were similar to other areas of the jaw bones $(\mathrm{P}>0.05)$. The lowest changes in BMD were observed in the apical horizontal, which is explained by the remoteness of this area from the inflammation source localized in the interalveolar septa $(\mathrm{P}<0.001)$.

Separate mention should be made of the significant dependency of the peculiarities of localization of the destructive process on the BMD parameters among the patients with generalized periodontitis. In patients suffering from generalized periodontitis of the III type with predominant vertical type of destruction of the bone tissue, the BMD parameters in certain areas were reduced to $600 \mathrm{H}$. The determined reduction of the mineral density was followed by disorders in the bone structure manifested by loss of clarity in the trabecular pattern, which was clearer in the upper part of the septa, enlargement of the intratrabecular cavities; thinning of the trabeculae. The described pattern of the pathological process is related to its localization mostly in the areas of cancellous bone tissue, where the metabolic processes take place very actively. Thus, in the abovementioned observations, the bone tissue was affected by active resorption, which was manifested in rapid decrease in the BMD parameters.

The greatest decrease in the BMD parameters was observed in the alveolar horizontal among the patients suffering from generalized periodontitis which developed following systemic osteoporotic changes in the bone tissue (main groups I and II). The determined parameters of these groups were higher compared to the comparison groups I and II by $12.3 \pm 3.2 \%(\mathrm{P}>0.05)$ and $14.1 \pm 3.5 \%(\mathrm{P}>0.05)$ on average respectively and by $24.0 \pm 4.1 \%(\mathrm{P}<0.01)$ and $32.1 \pm 4.6 \%(\mathrm{P}<$ $0.001)$ respectively compared to the control group.

However, later, in the process of treatment, we observed gradual normalization of the parameters of mineral bone density among the patients of both experimental groups $(\mathrm{P}<0.001)$. One month after the beginning of the treatment, the BMD parameters of the II group of comparison had practically normalized and were close to the parameters of the control, maintaining at this level throughout the monitoring $(\mathrm{P}>0.05)$. In the II group of comparison, the BMD parameters recovered gradually, which was manifested in clinical-X-ray stabilization of the pathological process in the periodontal tissues, though they did not equalize with the parameters of the control $(\mathrm{P}>0.05)$.

At the same time, mineral density of the bone tissue of the patients with generalized periodontitis of the II type (main group I), despite the treatment, remained practically unchanged, and 3 months after the beginning of the treatment it had increased only by $6.1 \pm 1.8 \%$ from the initial parameters $(\mathrm{P}>0.05)$. A similar insignificant increase was recorded in the next monitoring period. By contrast, during the treatment, the patients of main group II were observed to have a negative dynamic of the BMD parameters. Therefore, 1 month after the beginning of the treatment, the mineral density of the bone tissue had decreased by $4.2 \pm 1.2 \%$ on average from the initial parameters, and after 3 months - by $6.5 \pm 1.8 \%$, having stabilized and demonstrating an insignificant positive dynamic 6 months after the beginning of the treatment $(\mathrm{P}>0.05)$.

The results of the conducted biochemical studies, presented in Table 2, indicated that the level of total calcium in the blood before the treatment of generalized periodontitis in the comparison groups was within the norm, whereas in the main groups, we recorded a statistically reliable decrease of this indicator compared to the control $(\mathrm{P}<$ 0.05). A similar difference was observed during 3 months after the beginning of treatment in main group I. Moreover, in main group II, the normalization of the calcium level in the blood serum was not recorded even 6 months after the beginning of the treatment.

\section{Table 1}

The dynamic of parameters of the mineral density of bone tissue (BMD) in different areas of the alveolar process among the patients of the main groups $(n=49)$ and the groups of comparison $(n=55)$ during the treatment compared to the control $(M \pm m, n=20)$

\begin{tabular}{|c|c|c|c|c|c|}
\hline & Group & Alveolar horizontal & Middle horizontal & Apical horizontal & Septal vertical \\
\hline & Control & $1244.2 \pm 78.6$ & $1397.7 \pm 106.1$ & $1324.1 \pm 84.3$ & $1276.3 \pm 98.4$ \\
\hline \multirow{8}{*}{ Comparison } & \multirow{4}{*}{$\begin{array}{l}\text { before treatment } \\
\text { after } 1 \text { month } \\
\text { after } 3 \text { months } \\
\text { after } 6 \text { months }\end{array}$} & $1077.6 \pm 127.2$ & $1285.8 \pm 107.3$ & $1301.8 \pm 142.4$ & $1126.6 \pm 152.7$ \\
\hline & & $1024.6 \pm 131.4$ & $1257.8 \pm 96.8$ & $1328.7 \pm 153.5$ & $1103.8 \pm 111.9$ \\
\hline & & $1037.6 \pm 118.4$ & $1287.8 \pm 129.9$ & $1355.5 \pm 162.1$ & $1174.6 \pm 98.8$ \\
\hline & & $1193.3 \pm 95.9$ & $1341.4 \pm 124.2$ & $1343.8 \pm 146.6$ & $1216.7 \pm 139.8$ \\
\hline & \multirow{4}{*}{$\begin{array}{l}\text { before treatment } \\
\text { after } 1 \text { month } \\
\text { after } 3 \text { months } \\
\text { after } 6 \text { months }\end{array}$} & $983.9 \pm 10.3^{*}$ & $1131.4 \pm 95.3$ & $1298.1 \pm 118.1$ & $982.5 \pm 102.4^{*}$ \\
\hline & & $978.4 \pm 182.2$ & $1145.2 \pm 88.9$ & $1316.4 \pm 125.7$ & $969.7 \pm 96.8^{*}$ \\
\hline & & $1027.1 \pm 18.3$ & $1257.4 \pm 120.1$ & $1311.6 \pm 131.5$ & $1096.4 \pm 128.3$ \\
\hline & & $1144.6 \pm 118.4$ & $1314.2 \pm 129.9$ & $1320.8 \pm 176.6$ & $1177.6 \pm 119.4$ \\
\hline \multirow{8}{*}{ Main } & \multirow{4}{*}{$\begin{array}{l}\text { before treatment } \\
\text { after } 1 \text { month } \\
\text { after } 3 \text { months } \\
\text { after } 6 \text { months }\end{array}$} & $945.4 \pm 78.1^{* *}$ & $1101.7 \pm 100.6^{*}$ & $1139.4 \pm 145.3$ & $982.7 \pm 106.5^{*}$ \\
\hline & & $958.2 \pm 148.3$ & $1145.8 \pm 97.3$ & $1032.6 \pm 117.4^{*}$ & $1002.3 \pm 93.4^{*}$ \\
\hline & & $967.7 \pm 132.6$ & $1159.6 \pm 134.6$ & $1150.1 \pm 120.9$ & $1020.8 \pm 114.7$ \\
\hline & & $1046.1 \pm 84.5$ & $1201.1 \pm 107.8$ & $1158.3 \pm 14.7$ & $1059.7 \pm 138.2$ \\
\hline & \multirow{4}{*}{$\begin{array}{l}\text { before treatment } \\
\text { IIter one month } \\
\text { after } 3 \text { months } \\
\text { after } 6 \text { months }\end{array}$} & $844.8 \pm 79.6^{* * *}$ & $978.3 \pm 135.8^{*}$ & $1025.4 \pm 115.1^{*}$ & $880.4 \pm 125.3^{*}$ \\
\hline & & $812.7 \pm 140.9^{*}$ & $936.1 \pm 123.2^{* *}$ & $1048.2 \pm 105.4^{*}$ & $829.4 \pm 136.1^{*}$ \\
\hline & & $795.6 \pm 151.2^{*}$ & $922.8 \pm 147.5^{*}$ & $1109.6 \pm 123.6$ & $826.3 \pm 122.3^{* *}$ \\
\hline & & $887.3 \pm 133.8^{*}$ & $1020.5 \pm 158.1$ & $1143.5 \pm 128.7$ & $893.8 \pm 133.4^{*}$ \\
\hline
\end{tabular}

Note: $*_{-}$the difference is statistically reliable at $\mathrm{P}<0.05, * *-\mathrm{P}<0.01, * * *-\mathrm{P}<0.001$ compared to the parameters of the control.

In the experimental groups, at the beginning of the treatment, the level of phosphorus in the blood of patients with generalized periodontitis of the III type was higher than the control parameters $(\mathrm{P}<0.05)$, indicating the prevalence of the bone resorption over the processes of bone tissue formation, unrelated to the mineral density of the skeleton.

However, in comparison group II, we recorded a decrease in the concentration of phosphorus in the blood serum to its normalization already in the $3 \mathrm{rd}$ month since the treatment began $(\mathrm{P}<0.05)$. By contrast, in all patients of the main groups the level of blood phosphates remainned significantly lower than the parameters of the control throughout the study. Also, the prevailing of bone tissue resorption over the processes of its regeneration was indicated by the $\mathrm{Ca} / \mathrm{P}$ proportion which was much lower than 1.0. In the patients with generalised periodontitis in the main groups I and II this indicator equaled $0.82 \pm$ 0.08 and $0.63 \pm 0.07$ respectively $(\mathrm{P}<0.05$ compared to the control).

As we see in Table 2, the systemic osteoporotic phenomenon among the patients with generalized periodontitis was manifested in increase in the concentration of $\beta$-CrossLaps fragments in the urine $(\mathrm{P}<0.05)$. And despite the fact that during the study, the patients of the main groups I and II were observed to exhibit a tendency towards decrease in its secretion, this parameter remained heightened even during the period remote from the beginning of the treatment, which indicates 
resorption which gradually involved previously unaffected areas of the alveolar bone, and also possible progression of osteoporotic changes in other areas of bone.

A positive change in the process of bone recovery among the patients with generalized periodontitis was the normalization of the level of acid bone phosphatase a month after the treatment started in the I main group and 3 months after the beginning - in main group II $(\mathrm{P}<0.001)$. Similar dynamic indicates gradual transformation of progressive resorption of bone tissue in its latent process with following decrease in the total proinflammatory potential as a result of the treatment.

Table 2

Changes in the biochemical parameters of metabolism of bone tissue in the blood and urine of the patients of the main groups $(n=49)$ and comparison groups $(n=55)$ over the treatment process compared to the control $(M \pm m, n=20)$

\begin{tabular}{|c|c|c|c|c|c|c|c|c|c|}
\hline & Group & TRAP, U/1 & $\begin{array}{c}\beta \text {-CrossLaps, } \\
\text { ng/g } \\
\text { creatinine }\end{array}$ & $\begin{array}{l}\text { Osteocalcin, } \\
\mathrm{ng} / \mathrm{mol}\end{array}$ & $\mathrm{BAP}, \mathrm{U} / 1$ & CICP, ng/mol & $\begin{array}{c}\text { Parathormone, } \\
\text { pg/mol }\end{array}$ & $\begin{array}{l}\text { Total blood } \\
\text { calcium, } \\
\text { mmol/l }\end{array}$ & $\begin{array}{c}\begin{array}{c}\text { Total non- } \\
\text { organic } \\
\text { phosphorus of } \\
\text { blood, mmol/1 }\end{array}\end{array}$ \\
\hline & Control & $4.86 \pm 0.14$ & $1.02 \pm 0.05$ & $16.64 \pm 0.43$ & $10.73 \pm 0.34$ & $61.82 \pm 2.45$ & $47.84 \pm 3.27$ & $2.32 \pm 0.11$ & $1.91 \pm 0.16$ \\
\hline \multirow{8}{*}{ Comparison } & before trea & $5.20 \pm 0.16$ & $1.12 \pm 0.09$ & $16.45 \pm 0.44$ & $11.82 \pm 0.43$ & $60.73 \pm 2.56$ & $46.78 \pm 3.41$ & $2.21 \pm 0.12$ & $2.05 \pm 0.21$ \\
\hline & \multirow{3}{*}{$\begin{array}{l}\text { I after } 1 \text { month } \\
\text { after } 3 \text { months } \\
\text { after } 6 \text { months }\end{array}$} & $5.11 \pm 0.17$ & $1.09 \pm 0.07$ & $18.22 \pm 0.48^{*}$ & $11.59 \pm 0.33$ & $68.02 \pm 2.48$ & $47.12 \pm 3.37$ & $2.18 \pm 0.14$ & $1.98 \pm 0.18$ \\
\hline & & $5.15 \pm 0.08$ & $1.04 \pm 0.08$ & $17.93 \pm 0.57$ & $11.52 \pm 0.38$ & $71.09 \pm 2.63^{*}$ & $46.84 \pm 2.82$ & $2.38 \pm 0.11$ & $2.07 \pm 0.15$ \\
\hline & & $5.05 \pm 0.13$ & & $18.64 \pm 0.65^{*}$ & & $64.30 \pm 2.57$ & $47.51 \pm 3.25$ & & $1.86 \pm 0.12$ \\
\hline & before treatment & $5.68 \pm 0.21 *$ & $1.22 \pm 0.08^{*}$ & $15.31 \pm 0.55$ & $9.01 \pm 0.58^{*}$ & $51.93 \pm 2.89^{*}$ & $48.15 \pm 2.92$ & $2.12 \pm 0.19$ & $2.38 \pm 0.14^{*}$ \\
\hline & \multirow{3}{*}{ 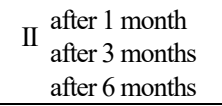 } & $5.34 \pm 0.26$ & $1.14 \pm 0.11$ & $16.97 \pm 0.45$ & $9.23 \pm 0.67$ & $75.42 \pm 3.01 * *$ & $48.02 \pm 3.19$ & $2.37 \pm 0.14$ & $2.31 \pm 0.23$ \\
\hline & & $5.24 \pm 0.24$ & $1.12 \pm 0.09$ & $19.14 \pm 0.62 * *$ & $9.55 \pm 0.51$ & $71.72 \pm 2.92 *$ & $47.48 \pm 3.91$ & $2.41 \pm 0.16$ & $2.24 \pm 0.19$ \\
\hline & & $5.18 \pm 0.17$ & $1.09 \pm 0.07$ & $17.97 \pm 0.56$ & $9.76 \pm 0.46$ & $66.76 \pm 2.61$ & $47.12 \pm 4.06$ & $2.25 \pm 0.14$ & $2.03 \pm 0.17$ \\
\hline \multirow{8}{*}{ Main } & \multirow{4}{*}{ 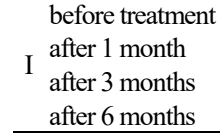 } & $5.59 \pm 0.32 *$ & $1.26 \pm 0.10^{*}$ & $14.61 \pm 0.63^{*}$ & $8.69 \pm 0.58 * *$ & $47.85 \pm 3.04 * *$ & $59.22 \pm 3.87^{*}$ & $1.85 \pm 0.18^{*}$ & $2.04 \pm 0.20$ \\
\hline & & $5.02 \pm 0.30$ & $1.23 \pm 0.12$ & $16.31 \pm 0.44$ & $9.08 \pm 0.56^{*}$ & $53.17 \pm 2.58^{*}$ & $56.75 \pm 3.09$ & $1.95 \pm 0.16$ & $2.14 \pm 0.16$ \\
\hline & & $4.74 \pm 0.27$ & $1.27 \pm 0.11 *$ & $15.57 \pm 0.56$ & $9.31 \pm 0.53 *$ & $58.73 \pm 2.85$ & $53.16 \pm 2.64$ & $2.09 \pm 0.15$ & $1.92 \pm 0.14$ \\
\hline & & $4.81 \pm 0.24$ & $1.22 \pm 0.08^{*}$ & $16.03 \pm 0.48$ & $9.42 \pm 0.56$ & $59.35 \pm 2.63$ & $53.73 \pm 3.03$ & $2.23 \pm 0.17$ & $1.85 \pm 0.15$ \\
\hline & \multirow{4}{*}{$\begin{array}{l}\text { II after } 1 \text { month } \\
\text { after } 3 \text { months } \\
\text { after } 6 \text { months }\end{array}$} & $5.83 \pm 0.28^{* *}$ & $1.33 \pm 0.10^{* *}$ & $13.31 \pm 0.59 * * *$ & $8.39 \pm 0.52 * * *$ & $45.75 \pm 2.93 * * *$ & $61.49 \pm 4.42 *$ & $1.74 \pm 0.21 *$ & $2.35 \pm 0.11^{*}$ \\
\hline & & $5.73 \pm 0.25^{* *}$ & $1.28 \pm 0.11^{*}$ & $13.65 \pm 0.62 * * *$ & $8.58 \pm 0.51 * *$ & $48.23 \pm 3.02 * *$ & $58.61 \pm 4.15^{*}$ & $1.79 \pm 0.23 *$ & $2.30 \pm 0.10^{*}$ \\
\hline & & $5.23 \pm 0.33$ & $1.30 \pm 0.11 *$ & $14.15 \pm 0.64^{* *}$ & $8.80 \pm 0.48^{* *}$ & $54.37 \pm 2.76^{*}$ & $48.03 \pm 3.89$ & & $2.18 \pm 0.18$ \\
\hline & & $5.16 \pm 0.31$ & $1.25 \pm 0.10^{*}$ & $14.88 \pm 0.59 *$ & $8.97 \pm 0.45^{* *}$ & $55.11 \pm 2.54$ & $47.22 \pm 3.95$ & $1.90 \pm 0.19$ & $2.16 \pm 0.22$ \\
\hline
\end{tabular}

Note: $*$ - difference is statistically significant at $\mathrm{P}<0.05, * *-\mathrm{P}<0.01, * * *-\mathrm{P}<0.001$ compared to the parameters of the control.

The highest level of alkaline phosphatase, which indicates the active processes of collagen synthesis in the bone tissue, was observed among the patients of comparison group I, whereas, the patients of the main groups and comparison group II had low values of this parameter $(\mathrm{P}<0.05)$. In the patients with generalized periodontitis of the III type, which followed osteoporotic changes in the skeleton, the activity of the bone alkaline phosphatase decreased from the control values by $21.8 \pm$ $4.2 \%(\mathrm{P}<0.001)$. The latter, perhaps, was caused by the inhibition of the functional activity of the osteoblasts which accompanied the damage to a large volume of the bone tissue, which occurred among the patients.

At the same time, the level of parathormone in all the experimental groups remained within the norm, though in the main groups, we observed a tendency towards the increase of its level to the upper border of the norm, caused by low level of calcium in the blood. Excessive secretion of parathormone following the hypocalcaemia additionally activates osteoprotegerin, which justifies the prescription of the calcium preparations and vitamin complexes during treatment of destructive forms of generalized periodontal disease (Leonova et al., 2013; Hellstein et al., 2011).

It is interesting that the dynamic of changes in the level procollagen type 1 C-terminal propeptide (CICP) in the blood plasma, which describes the activity of osteoblasts, was different from the pattern of changes of other parameters of osteoregeneration. The highest CICP level observed in comparison groups I and II indicates that despite that decrease in the mineral density of bone tissue of bones of the jaw and significant prevalence of bone resorption over osteosynthesis among the abovementioned patients, the process of bone tissue recovery is developing at a sufficient level. Also, we should mention that the CICP level in the blood plasma normalized 1-3 months after the beginning of the treatment among the patients of the comparison groups. However, in the patients of the main groups the initial CICP level, which was lower by $22.6 \pm 4.0 \%$ compared to the control (by $26.0 \pm 4.3 \%$ for the main group II), normalized only $3-6$ months after the treatment $(\mathrm{P}<0.05)$.

The same dynamic was observed for the parameters of bone alkaline phosphatase and osteocalcin (Table 2). However, due to significant variation of its parameters, the determined differences compared to the control were statistically unreliable $(\mathrm{P}>0.05)$. On the whole, the determined difference of the parameters of the bone formation reflects the decrease in the activity of the osteoregeneration processes among the patients with generalized periodontitis, who had osteoporotic changes in the entire skeleton.

After generalization and analysis of the quantitative parameters determined for the experimental groups during different periods of the treatment, we conducted a correlation-regressional analysis for determining the most significant relations between the indicators of mineral density of the bone tissue (BMD) and biochemical markers of bone metabolism. For the abovementioned analysis, we selected the parameters which changed the most during the treatment: mineral density of the bone tissue in the alveolar and middle horizontal, concentration of tartrate-resistant acid phosphatase (TRAP), bone alkaline phosphatase, procollagen type $1 \mathrm{C}$-terminal propeptide (CICP) in the blood and $\beta$ CrossLaps fragments in urine. The calculated correlational relations are presented in the Table 3 and 4.

\section{Table 3}

Correlational relationships (r) between the parameters of bone tissue mineral density of the lower jaw in alveolar horizontal and biochemical parameters of bone tissue metabolism among the patients of the experimental groups during the treatment $(n=104)$

\begin{tabular}{|c|c|c|c|c|c|}
\hline & Group & TRAP & $\beta$-CrossLaps & BAP & $\mathrm{CICP}$ \\
\hline \multirow{8}{*}{ Comparison } & before treatment & $-0.325^{*}$ & $-0.315^{*}$ & 0.205 & 0.232 \\
\hline & after 1 month & -0.282 & $-0.275^{*}$ & $0.252 *$ & 0.268 \\
\hline & 1 after 3 months & -0.216 & -0.246 & -0.178 & $0.271^{*}$ \\
\hline & after 6 months & -0.188 & -0.163 & 0.211 & 0.234 \\
\hline & before treatment & $-0.368^{*}$ & $-0.386^{* *}$ & -0.188 & 0.214 \\
\hline & after 1 month & -0.327 & -0.325 & 0.155 & 0.247 \\
\hline & II after 3 months & $-0.264^{*}$ & $-0.341^{*}$ & $0.236^{*}$ & $0.281 *$ \\
\hline & after 6 months & -0.180 & -0.307 & -0.146 & $0.319 * *$ \\
\hline \multirow{8}{*}{ Main } & before treatment & $-0.325^{*}$ & $-0.345^{*}$ & 0.172 & 0.283 \\
\hline & after 1 month & -0.276 & $-0.308^{*}$ & -0.134 & 0.250 \\
\hline & after 3 months & -0.294 & -0.286 & 0.180 & $0.341 *$ \\
\hline & after 6 months & -0.209 & -0.262 & $0.216^{*}$ & $0.294 *$ \\
\hline & before treatment & $-0.292 *$ & $-0.348 * *$ & 0.208 & 0.217 \\
\hline & after 1 month & $-0.267 *$ & $-0.312 *$ & 0.141 & 0.194 \\
\hline & II after 3 months & -0.283 & $-0.285^{*}$ & -0.187 & $0.312 *$ \\
\hline & after 6 months & -0.227 & -0.251 & 0.235 & $0.282 *$ \\
\hline
\end{tabular}

Note: * - the difference is statistically reliable at $\mathrm{P}<0.05, * *-\mathrm{P}<0,01$. 
After the relationships between the mineral density of the jaws in the alveolar horizontal (BMD) and parameters of bone tissue metabolism were calculated, in the main groups and comparison groups, we found a relatively low and average negative relation between this parameter and TRAP concentration in the blood and $\beta$-CrossLaps in the urine during the first three months of monitoring $(\mathrm{P}<0.05)$. It is interesting that the further correlation of the abovementioned parameters had a low level of probability $(\mathrm{P}>0.05)$, which indicates the impact of proinflammatory markers on the destruction of bone tissue, and, therefore, the values of the BMD parameters at the beginning of the treatment. However, during the treatment, the levels of the abovementioned markers gradually decreased and their impact on the parameters of bone mineral density was reduced (see Table 3 ).

For both experimental groups, we calculated a low positive correlational relationship between bone mineral density and CICP concentration in the blood plasma, which had a sufficient level of significance, beginning from the third month of monitoring $(\mathrm{P}<0.05)$. In our opinion, it was present due to the BMD dependency on the balance between the proinflammatory and osteoregenerating factors, and its changes were caused by the increase in the activity of the processes of bone tissue mineralization which occurred in the final stage of osteoregeneration a few months after the beginning of treatment. At the same time, in comparison group I, the correlational relation was less significant due to lower loss of the bone mass, i.e. a lower impact of these markers on the bone mineral density parameter.

During the comparison of bone mineral density of the alveolar process in the middle horizontal and the indicators of bone tissue metabolism (see Table 4) among the patients of the main group, we determined a statistically significant average negative relation in the main groups with $\beta$-CrossLaps concentration throughout the monitoring and a low relation with TRAP at the beginning of the treatment $(\mathrm{P}<0.05)$. In comparison group II, a similar pattern was determined until the third month of monitoring.

Perhaps, the presence of the abovementioned relations is due to the fact that bone tissue of the alveolar process in the middle horizontal is not directly involved in the inflammatory process in patients with generalized periodontitis, i.e., its resorption level is less than TRAP-conditioned, therefore following osteoporosis, the bone mineral density depends also on other components of the bone homeostasis. This is proved by the extent of correlation of this parameter, which remained quite high with the $\beta$-CrossLaps concentration $(\mathrm{P}<0.05)$.

\section{Table 4}

Correlation relations (r) between the parameters of bone mineral density of the lower jaw in the middle horizontal and biochemical parameters of bone tissue metabolism among the patients of experimental groups in the process of treatment $(n=104)$

\begin{tabular}{|c|c|c|c|c|c|}
\hline & Group & TRAP & $\beta$-CrossLaps & BAP & CICP \\
\hline \multirow{8}{*}{ Comparison } & before treatment & $-0.218^{*}$ & $-0.242^{*}$ & 0.145 & 0.232 \\
\hline & after 1 month & -0.223 & -0.197 & $0.242 *$ & $0.261^{*}$ \\
\hline & 1 after 3 months & -0.148 & $-0.236^{*}$ & -0.173 & $0.284 *$ \\
\hline & after 6 months & -0.167 & -0.192 & 0.215 & 0.220 \\
\hline & before treatment & $-0.203^{*}$ & $-0.328^{*}$ & 0.262 & 0.237 \\
\hline & after 1 month & $-0.176^{*}$ & $-0.222 *$ & 0.125 & $0.277^{*}$ \\
\hline & II after 3 months & -0.144 & $-0.291^{*}$ & -0.136 & $0.291 *$ \\
\hline & after 6 months & -0.159 & -0.247 & 0.182 & $0.269^{*}$ \\
\hline \multirow{8}{*}{ Main } & before treatment & $-0.274^{*}$ & $-0.302 *$ & 0.153 & 0.186 \\
\hline & after 1 month & -0.240 & $-0.268^{*}$ & 0.164 & 0.217 \\
\hline & 1 after 3 months & -0.193 & -0.227 & 0.207 & $0.251^{*}$ \\
\hline & after 6 months & -0.162 & -0.245 & -0.118 & $0.234^{*}$ \\
\hline & before treatment & $-0.217^{*}$ & $-0.343 * *$ & 0.151 & 0.226 \\
\hline & II after 1 month & $-0.182 *$ & $-0.322 *$ & 0.170 & $0.254 *$ \\
\hline & II after 3 months & -0.168 & $-0.279 *$ & $0.183^{*}$ & $0.272 *$ \\
\hline & after 6 months & -0.151 & $-0.258 *$ & -0.174 & $0.308^{*}$ \\
\hline
\end{tabular}

Note: * difference was statistically reliable at $\mathrm{P}<0.05$.

Finally, a low positive correlational relationship between BMD and CICP concentration was determined in the comparison groups from the first month of monitoring, whereas in the main groups this began in the third month $(\mathrm{P}<0.05)$. This allows us to conclude that the CICP is good at reflecting the processes of osteoregeneration and remineralization of bone tissue which was not directly involved in the inflammatory-dystrophic process.

Finally, we should summarize the data obtained over the treatment of the patients with generalized periodontitis in the different experimental groups. The highest percentage of stable remissions 6 months after the treatment begun was recorded in the Ist main group and the Ist comparison group, i.e. among the patients with generalized periodontitis of the II type, who had osteoporotic changes in the skeleton, or did not have them. The treatment efficiency parameters equaled $74.1 \pm 8.4 \%$ ( 20 of 27 ) respectively for the Ist main group and $78.3 \pm 8.6 \%$ (18 of 23$)$ for the I comparison group ( $P>0.05)$. Far worse results were observed in the II comparison group (patients with generalized periodontitis of the III type with no systemic involutory osteoporotic changes of bones), where the clinical-X-ray stabilization of the disease was observed only in $53.8 \pm 9.8 \%$ (14 of 26 ) of the observations $(\mathrm{P}<0.05)$. In the II main group, i.e. the patients with the periodontitis of the III type, which had developed following systemic osteoporotic disorders in the bone tissue, the stable remission 6 months from the beginning of the treatment was recorded only in 8 of 28 patients $(28.6 \pm 8.5 \%, \mathrm{P}<0.05)$. Therefore, the efficiency of the treatment significantly decreases in patients with advanced development of the inflammatory-dystrophic process in the tissues around the teeth. At the same time, the presence of systemic disorders in the bone metabolism complicates the clinical symptomatic, causes more significant imbalance of the resorption-regeneration processes in the alveolar bone, and, therefore complicates the treatment.

\section{Discussion}

Generalized periodontitis should be analyzed as an inflammatorydystrophic multi-factor process in the tissues around the teeth, the development of which depends both on genetic predisposition and external factors, and also individual peculiarities of the metabolic profile of the patient, and finally, the systemic diseases suffered by this patient (Wu et al., 2015; Tsepov et al., 2016; Souza et al., 2017).

Osteoporosis of involutary genesis is a non-favourable factor which complicates generalized periodontal disease, which, first of all, manifests in decrease of the bone mineral density (BMD), particularly the alveolar process (Bodduru et al., 2016). Considering the fact that the alveolar bone is within the source area of the inflammatory-destructive process initiated by the microbial invasion of the periodontal tissues, rapid progression of the bone resorption develops. Also, bone tissue with decreased mineral density has lower reserve potential for recovery, even after eradication of the main periodontopathogenic factors.

Therefore, it is pretty clear that without determining the causes of systemic disorders in the bone tissue, and also their elimination, it is practically impossible to achieve prolonged remission of generalized periodontal disease and eliminate the risk of development of relapse and progression of the pathological process (Mordasov \& Ivanjuta, 2016). Thus, it is recommended to supplement the main complex treatment of generalized periodontosis by calcium preparations, mineral complexes, and preparations which normalize metabolic processes, particularly in bone tissue (Hellstein et al., 2011; Leonova et al., 2013). Moreover, in cases of diagnosed osteoporosis of patients with generalized periodontal disease, it is recommended to prescribe antiosteoporotic preparations (Gorb-Gavril'chenko \& Strel'chenja, 2013; Aspalli et al., 2014). In our opinion, such an approach is entirely justified. However, treatment of osteoporosis cannot be within the competency of only a periodontist and requires participation of specialists in the field.

Certainly, prescribing antiresorptive preparations, as with monitoring the dynamic of changes in bone tissue as a result of treatment is impossible without determining the parameters of bone mineral density (BMD) and study of biochemical markers of bone metabolism.

As the results of our study indicate, bone mineral density changes in a nonuniform manner depending on the severity of generalized periodontosis and manifestation of osteoporotic changes in bone density. In our opinion, this is caused by the fact that the pattern of processes of destruction and recovery of the bone matrix is determined by 
proinflammatory, osteomodeling and osteoregeneration factors, the proportion of which changes and determines the condition of bone tissue at different stages of treatment.

The results we obtained indicate a close relationship between the treatment results and initial periodontal status of patients, i.e. much worse prognosis of treatment outcome in groups with higher level of disease severity, which is proved by the works by our colleagues (Bodduru et al., 2016; Bernal et al., 2018). On the other hand, we demonstrated that the systemic disorders in bone metabolism, particularly involutory genesis, radically complicate the inflammatory-dystrophic process in the tissues around the teeth, decreasing the efficiency of treatment. Therefore, there is a need to adjust the treatment protocol for the abovementioned patients.

\section{Conclusions}

The most diagnostically valuable indicators of the condition of bone tissue of patients with generalized periodontal disease of II-III type of severity following involutory osteoporosis with no systemic changes in mineral bone density are the parameters of bone mineral density of the alveolar bone (BMD), and also the $\beta$-CrossLaps level in urine and activity of tartrate-resistant acid phosphatase (TRAP) and bone alkaline phosphatase in the blood serum.

The most representative indicator of the inflammatory-destructive process in periodontal disease is decrease in bone mineral density in the alveolar part of jaw bones. This parameter decreases in patients with II type of severity by $13.4 \pm 3.2 \%$ compared to the control, and in patients with III type by $20.1 \pm 3.5 \%$ ( $(\mathrm{P}<0.05)$. Systemic osteopenic phenomena cause even greater decrease in this parameter to values which in patients with generalized periodontosis of II type of severity were $24.0 \pm 4.1 \%$ lower than the control level, and lower by $32.1 \pm$ $4.6 \%(\mathrm{P}<0.001)$ in patients with III type.

The lowest osteoregenerative activity occurred at the beginning of treatment of patients with generalized periodontal disease of III type, which followed systemic involutory osteoporosis. Therefore, the activity of bone alkaline phosphatase decreased by $21.8 \pm 4.0 \%$ compared to the control; tartrate-resistant acid phosphatase (TRAP) - by $20.0 \pm 3.9 \%$ respectively; concentration of procollagen type $1 \mathrm{C}$-terminal propeptide (CICP) - by $26.0 \pm 4.3 \%(\mathrm{P}<0.05)$.

The main proinflammatory markers on the BMD parameters gradually decrease in the process of treatment, whereas the positive dynamic of osteogenerative parameters indicate processes of bone tissue recovery, which is recorded only from the third month of monitoring. The mineral metabolism parameters have only supportive significance for assessing bone metabolism.

The patients suffering from generalized periodontal disease of III type of severity have a low negative relationship between mineral density of the alveolar part of the jaw bones and activity of TRAP in the blood $(\mathrm{r}=-0.292, \mathrm{P}<0.05)$ and relationship of average extent with concentration of $\beta$-CrossLaps in the urine $(r=-0.348, \mathrm{P}<0.01)$. At the same time, concentration of procollagen type $1 \mathrm{C}$-terminal propeptide positively correlates with bone mineral density from the third month after the start of the treatment $(\mathrm{r}=0.312, \mathrm{P}<0.05)$.

The diagnostic value of biochemical markers of bone tissue metabolism consists in determining the balance in the processes of resorption and formation, at different stages of generalized periodontal disease, which allows one to correctly select the treatment tactics, prescribe the correct pharmacotherapy and prevent the development of complications.

\section{References}

Aspalli, S. S., Shetty, V. S., Parab, P. G., Nagappa, G., Devnoorkar, A., \& Devarathnamma, M. V. (2014). Osteoporosis and periodontitis: Is there a possible link? Indian Journal of Dental Research, 25(3), 316-320.

Bernal, M., Elenkova, M., Evensky, J., \& Stein, S. H. (2018). Periodontal disease and osteoporosis - shared risk factors and potentiation of pathogenic mechanisms. Current Oral Health Reports, 5(2), 26-32.
Bodduru, R., Deshmukh, K., Chintawa, S., \& Nayyar, A. S. (2016). Osteoporosis and periodontal disease: Association and mechanisms: An indepth review. International Journal of Therapeutic Applications, 32, 11-19.

Borysenko, A. V., Politun, A. M., Nesin, O. F., \& Sydelnykova, L. F. (2005) Terapevtychna stomatolohiia. Rozdil 1. Protokoly nadannia stomatolohichnoi dopomohy [Therapeutic dentistry. Part 1 . Protocols for the provision of dental care]. Medytsyna, Kyiv (in Ukrainian).

Chambrone, L. (2016). Current status of the influence of osteoporosis on periodontology and implant dentistry. Current Opinion in Endocrinology and Diabetes and Obesity, 23(6), 435-439.

Chornij, A. V., \& Shmanko, V. V. (2017). Index assessment of the state of periodontal tissues in individuals with primary hypothyroidism. Clinical Dentistry, 3, 17-23.

Clark, D., Febbraio, M., \& Levin, L. (2017). Aggressive periodontitis: The unsolved mystery. Quintessence International, 48(2), 103-111.

Danilevskij, N. F., \& Borisenko, A. V. (2000). Zabolevanija parodonta [Periodontal diseases]. Zdorovye, Kyiv (in Russian).

Darcey, J., Devlin, H., Lai, D., Walsh, T., Southern, H., Marjanovic, E., \& Horner, K. (2013). An observational study to assess the association between osteoporosis and periodontal disease. British Dental Journal, 215(12), 617-621.

Dobrovol'skaya, O. V., Toroptsova, N. V., \& Smirnov, A. V. (2017). Instrumental'naya diagnostika osteoporoza na sovremennom etapye [Instrumental diagnostics of osteoporosis at the present stage]. Meditsinskiy Alfavit, 1(12), 11-15 (in Russian).

Fastovets, O. O. (2000). Systemni porushennia metabolizmu kistkovoi tkanyny u khvorykh na heneralizovanyi parodontyt [Systemic disorders of bone tissue metabolism in patients with generalized periodontitis]. Visnyk Stomatolohii, 2, 15-17 (in Ukrainian).

Filimonova, N. B., \& Fil', I. O. (2005). Statystychnyy analiz danykh vidpovidno do zasad naukovo obgruntovanoyi medytsyny. Porivnyannya hrup za kil'kisnymy pokaznykamy [Statistical analysis of data according to the principles of science-based medicine. Comparison of groups in quantitative terms]. Medytsyna Zaliznychnoho Transportu Ukrayiny, 4, 86-93 (in Ukranian).

Filimonova, N. B., Fil', I. O., \& Mykhaylova, T. S. (2004). Statystychnyy analiz danykh vidpovidno do zasad naukovo obgruntovanoyi medytsyny. Pervynnyy analiz kil'kisnykh danykh, podannya rezul'tativ eksperymentu [Statistical analysis of data according to the principles of sciencebased medicine. Initial analysis of quantitative data, presentation of experimental results]. Medytsyna Zaliznychnoho Transportu Ukrayiny, 4, 30-38 (in Ukranian).

Frencken, J. E., Sharma, P., Stenhouse, L., Green, D., Laverty, D., \& Dietrich, T. (2017). Global epidemiology of dental caries and severe periodontitis - A comprehensive review. Journal of Clinical Periodontology, 44 (18), 94-105.

Gajdarova, T. A., Fedotova, M. V., Eremina, N. A., Inshakov, D. V., \& Litvinova, T. K. (2006). Metod ispol'zovanija rentgenomorfometrii dlja ocenki mineral'noj plotnosti kostnoj tkani al'veoljarnoj kosti [The method of using X-ray morphometry to evaluate the mineral density of bone tissue of the alveolar bone]. Bulletin VSSC of the RAMS, 51, 2330 (in Russian).

Garnero, P. (2017). The utility of biomarkers in osteoporosis management. Molecular Diagnosis and Therapy, 21(4), 401-418.

Gorb-Gavril'chenko, I. V., \& Strel'chenja, T. N. (2013). Opyt lechenija generalizovannogo parodontita na fone ovariojektomii osteotropnymi preparatami [Experience in the treatment of generalized periodontitis against ovariectomy with osteotropic drugs]. Ukrainskyi Stomatolohichnyi Almanakh, 3, 42-46 (in Russian).

Goyal, L., Goyal, T., \& Gupta, N. D. (2017). Osteoporosis and periodontitis in postmenopausal women: A systematic review. Journal of Midlife Health, 8(4), 151-158.

Hellstein, J. W., Adler, R. A., Edwards, B., Edwards, B., Jacobsen, P. L., Kalmar, J. L., Koka, S., Migliorati, C. A., \& Ristic, H. (2011). Managing the care of patients receiving antiresorptive therapy for prevention and treatment of osteoporosis: Executive summary of recommendations from the American Dental Association Council on Scientific Affairs. Journal of American Dental Association, 142(11), 1243-1251.

Ignasiak, Z., Radwan-Oczko, M., Rozek-Piechura, K., Cholewa, M., Skrzek, A., Ignasiak, T., \& Slawinska T. (2016). Analysis of the relationships between edentulism, periodontal health, body composition, and bone mineral density in elderly women. Clinical Interventions in Aging, 11, 351-356.

Kapitanenko, A. M., \& Dochkin, I. I. (1988). Klinicheskij analiz laboratornyh issledovanij [Clinical analysis of laboratory studies]. Voennoe izdatel'stvo, Moscow (in Russian).

Karakov, K. G. (2016). Terapevticheskij podhod k lecheniju hronicheskogo generalizovannogo parodontita na fone sistemnogo osteoporoza [Therapeutic approach to the treatment of chronic generalized periodontitis in 
the context of systemic osteoporosis]. Meditsinskiy Alfavit, 2(9), 12-16 (in Russian).

Kinane, D. F., Stathopoulou, P. G., \& Papapanou, P. N. (2017). Periodontal diseases. Nature Reviews. Disease Primers, 22, 170-188.

Kirova, E. G., Konev, V. P., \& Suncova, T. V. (2009). Osobennosti techenija vospalitel'nyh zabolevanij parodonta u pacientov s displaziej soedinitel'noj tkani: Morfologicheskija harakteristika, principy klinicheskogo podhoda [Features of the course of inflammatory periodontal diseases in patients with connective tissue dysplasia: Morphological characteristics, principles of the clinical approach]. Institute of Stomatology, 4(45), 6869 (in Russian).

Kondrahin, I. P. (2004). Metody veterinarnoj klinicheskoj laboratornoj diagnostiki [Methods of veterinary clinical laboratory diagnostics]. Kolos, Moscow (in Russian).

Kolte, R. A., Kolte, A. P., \& Potey, A. M. (2017). Risk assessment of osteoporosis in pre- and postmenopausal periodontally healthy and chronic periodontitis women with digital panoramic radiographs. Journal of Indian Society of Periodontology, 21(6), 461-465.

Leonova, L. E., Kovtun, A. A., \& Pavlova, G. A. (2013). Sravnitel'naja ocenka effektivnosti lechenija bol'nyh parodontitom s primeneniem osteotropnyh preparatov [Comparative evaluation of the effectiveness of treatment of patients with periodontitis with the use of osteotropic drugs]. Parodontology, 18(1), 32-35 (in Russian).

Linden, G. J., Lyons, A., \& Scannapieco, F. A. (2013). Periodontal systemic associations: Review of the evidence. Journal of Clinical Periodontology, 40(14), 8-19.

Lu, R. F., Feng, X. H., Xu, L., \& Meng, H. X. (2015). Clinical and putative periodontal pathogens features of different sites with probing depth reduction after non-sergicalperiodontal treatment of patients with aggressive periodontitis. Beijing Da Xue Xue Bao, 47(1), 13-18.

Lu, H., Jiang, F., Guan, D., Lu, C., Guo, B., Chan, C., Peng, S., Liu, B., Guo, W., Zhu, H. L., Xu, X., Lu, A., \& Zhang, G. (2016). Metabolomics and its application in the development of discovering biomarkers for osteoporosis research. In: Mobasheri, A. (ed.). International Journal of Molecular Sciences, 17(12), 2018-2040.

Masheiko, I. V. (2017). Biohimicheskie markery v ocenke processov remodelirovanija kostnoj tkani pri osteopenii i osteoporoze [Biochemical markers in the evaluation of bone remodeling processes in osteopenia and osteoporosis]. Journal of Grodno State Medical University, 2, 149 153 (in Russian).

Mordasov, N. A., \& Ivanjuta, I. V. (2016). Sravnitel'noe issledovanie dvuh antirezorbtivnyh preparatov s raznym mehanizmom dejstvija pri lechenii hronicheskogo generalizovannogo parodontita na fone vtorichnogo osteoporoza [A comparative study of two antiresorptive drugs with different mechanisms of action in the treatment of chronic generalized periodontitis in the context of secondary osteoporosis]. Scientific Almanah, 5(3), 319-323 (in Russian).

Nakamoto, T., Taguchi, A., Ohtsuka, M., Suei, Y., Fujita, M., Tsuda, M., Sanada, M., Kudo, Y., Asano, A., \& Tanimoto, K. (2008). A computeraided diagnosis system to screen for osteoporosis using dental panoramic radiographs. Dental Maxillofacial Radiology, 37, 274-281.

Naot, D., \& Cornish, J. (2008). The role of peptides and receptors of the calcitonin family in the regulation of bone metabolism. Bone, 43(5), 813-818.

Penoni, D. C., Torres, S. R., Farias, M. L. F., Fernandes, T. M., Luiz, R. R., \& Leão, A. T. T. (2016). Association of osteoporosis and bone medication with the periodontal condition in elderly women. Osteoporosis International, 27(5), 1887-1896.

Rinčić, N., Božić, D., Rinčić, G., Gaćina, P., \& Plančak, D. (2016). Evaluation of periodontal parameters in patients with early stage chronic lymphocytic leukemia. Acta Stomatologica Croatica, 50(1), 23-33.

Roschger, P., Paschalis, E. P., Fratzl, P., \& Klaushofer, K. (2008). Bone mineralization density distribution in health and disease. Bone, 42(3), 456-466.

Sims, N. A., \& Gooi, J. H. (2008). Bone remodeling: Multiple cellular interactions required for coupling of bone formation and resorption. Seminars in Cell and Developmental Biology, 19(5), 444-451.

Siris, E. S., Adler, R., Bilezikian, J., Bolognese, M., Dawson-Hughes, B., Favus, M. J., Harris, S. T., Jan de Beur, S. M., Khosla, S., Lane, N. E., Lindsay, R., Nana, A. D., Orwoll, E. S., Saag, K., Silverman, S., \& Watts, N. B. (2014). The clinical diagnosis of osteoporosis: A position statement from the National Bone Health Alliance Working Group. Osteoporosis International, 25(5), 1439-1443.

Souza, A. J., Gomes-Filho, I. S., Silva, C. A. L., Passos-Soares, J. S., Cruz, S. S., Trindade, S. C., Figueiredo, A. C. M. G., Buischi, Y. P., Seymour, G. J., \& Cerqueira, E. M. M. (2017). Factors associated with dental caries, periodontitis and intra-oral lesions in individuals with HIV/AIDS. AIDS Care, 1-8.

Tsepov, L. M., Tsepova, E. L., \& Tsepov, A. L. (2016). Sochetannaja patologija: Vospalitel'nye zabolevanija parodonta, osteoporoz, deficit vitamina D [Combined pathology: Inflammatory periodontal diseases, osteoporosis, vitamin D deficiency]. Parodontology, 21(4), 4-9 (in Russian).

Wang, C. W. J., \& McCauley, L. K. (2016). Osteoporosis and periodontitis. Current Osteoporosis Reports, 14(6), 284-291.

Winning, L., \& Linden, G. J. (2017). Periodontitis and systemic disease: Association or causality? Current Oral Health Reports, 4(1), 1-7.

Wu, Y. Y., Xiao, E., \& Graves, D. T. (2015). Diabetes mellitus related bone metabolism and periodontal disease. International Journal of Oral Science, 7(2), 63-72. 